\title{
CALCAREOUS NANNOFOSSILS AND PALYNOMORPHS FROM PLIENSBACHIAN-TOARCIAN BOUNDARY IN LUSITANIAN BASIN, PORTUGAL
}

\author{
LUIZ CARLOS VEIGA DE OLIVEIRA, RODOLFO DINO \\ Cenpes, PETROBRAS, Cidade Universitária, Ilha do Fundão, 21941-598, Rio de Janeiro, Brazil. \\ lcveiga@petrobras.com.br,dino@petrobras.com.br
}

LUIS VITOR DUARTE

Departamento de Ciências da Terra, Centro Geociências, F.C.T., Universidade de Coimbra, 3000-272, Coimbra, Portugal.lduarte@ci.uc.pt

NICOLA PERILLI

Dipartimento di Scienze della Terra, Università degli Studi di Pisa, Via S. Maria, 53, 56100, Pisa, Italy. perilli@dst.unipi.it

\begin{abstract}
The Pliensbachian/Toarcian boundary (Lower Jurassic) is well represented in the Lusitanian Basin (Portugal), mainly in Peniche area, where more than $450 \mathrm{~m}$ of marls and limestones are exposed. These deposits were chosen as a candidate for the Toarcian Global Stratotype Section and Point (GSSP). Calcareous nannofossil and palynomorph assemblages are described herein, with the aim to contribute to the GSSP definition. Marly samples were collected $3 \mathrm{~m}$ below and $15 \mathrm{~m}$ above this boundary and analyzed for calcareous nannofossils and palynomorphs. The main nannofossils observed were: Biscutum finchii, B. grande, Calcivascularis jansae, Crepidolithus crassus, C. granulatus, C. impontus, Lotharingius hauffii, L. sigillatus, L. velatus, Schizosphaerella spp. and Tubirhabdus patulus. This assemblage indicates that the Pliensbachian/Toarcian boundary in Peniche lies in the upper part of the NJ5b Subzone. Schizosphaerella and Lotharingius dominate the assemblage. The abundant occurrence of $C$. jansae and the common occurrence of $B$. grande indicate a strong Tethyan influence. The palynomorphs were, in general, fairly well-preserved with low diversity and common small forms. The residue is dominated by slightly carbonized woody organic material. Corollina (rimulates) dominates all samples and trilete spores form a significant component of the assemblage. Dinoflagellate cysts are common in the lower part of the section sampled. The relatively high percentage of rimulates indicates a hot climate. The abundance of organic residue in woody material indicates that a strong influx of continental debris invaded the carbonate platform during the Toarcian.
\end{abstract}

Key words: calcareous nannofossils, Palynology, Pliensbachian, Toarcian, Lusitanian Basin, Portugal.

RESUMO - O limite Pliensbaquiano/Toarciano (Jurássico inferior) está bem representado na bacia Lusitânica (Portugal), principalmente em Peniche, onde afloram mais de $450 \mathrm{~m}$ de margas e calcários. Os depósitos de Peniche foram escolhidos como um dos candidatos ao estabelecimento do GSSP do Toarciano. Visando contribuir para essa definição, são descritas aqui as assembléias de nanofósseis e de palinomorfos ocorrentes nesses depósitos. Análises de nanofósseis e de palinologia foram realizadas em amostras de margas coletadas $3 \mathrm{~m}$ abaixo e $15 \mathrm{~m}$ acima deste limite. Os principais nanofósseis observados foram: Biscutum finchii, B. grande, Calcivascularis jansae, Crepidolithus crassus, C. granulatus, C. impontus, Lotharingius hauffii, L. sigillatus, L. velatus, Schizosphaerella spp. e Tubirhabdus patulus. Esta assembléia, aliada ao aparente posicionamento das amostras acima da extinção de Crucirhabdus primulus, indica que o limite PliensbaquianoToarciano estaria localizado na parte superior da subzona NJ5b. Os gêneros Schizosphaerella e Lotharingius dominam numericamente a assembléia, também caracterizada pela ocorrência abundante de $C$. jansae e comum de $B$. grande, indicadores de forte influência de águas do Tétis. A associação palinológica recuperada se apresenta, de modo geral, com baixo grau de preservação, pouco diversificada, com formas pequenas e domínio de matéria orgânica lenhosa, algo carbonizada. Predominam as formas rimuladas do gênero Corollina, sendo os esporos triletes um componente importante nas associações. Os dinoflagelados são comuns na porção mais inferior da seção. O relativo alto percentual dos rimulados indica um clima quente à época de deposição. O resíduo orgânico rico em material lenhoso indica um forte influxo de material continental, detrítico, invadindo a plataforma carbonática instalada, particularmente a partir do Toarciano.

Palavras-chave: nanofósseis calcários, Palinologia, Pliensbaquiano, Toarciano, bacia Lusitânica, Portugal. 


\section{INTRODUCTION}

The high biostratigraphic potential of the Lower Jurassic calcareous nannofossils is well documented in Bown (1987), Bown et al. (1988), Kaenel et al. (1996), Bown \& Cooper (1998), and Mattioli \& Erba (1999). Their works were based on calcareous nannofossils recovered from many sections located in northwest Europe and the Mediterranean. The biohorizon succession and the calcareous nannofossil zones and subzones proposed for northwest Europe (Hettangian to Tithonian) and Italy and south of France (Hettangian to Callovian) were discussed by Bown \& Cooper (1998) and Mattioli \& Erba (1999), respectively.

As a part of a multidisciplinary work, data is also available on Pliensbachian to Aalenian calcareous nannofossil assemblages recovered from different sections along the western (Lusitanian Basin) and northeastern (Basque Cantabrian area and Iberian Range) margins of the Iberian Massif. In particular, the Pliensbachian/Toarcian calcareous nannofossil data set retrieved from the BasqueCantabrian area (Perilli, 1999, 2000; Perilli \& Comas-Rengifo, 2002) was discussed by Perilli et al. (2004). Previously studied by Hamilton $(1977,1979)$, Bown (1987) and Kaenel et al. (1996), the Toarcian calcareous nannofossils of the Lusitanian Basin have been investigated by Perilli \& Duarte (2003), Duarte et al. (2004a) and Perilli \& Duarte (2006). These works were focused on the Sinemurian/Pliensbachian and
Aalenian calcareous nannofossils recovered from sections in the Lusitanian Basin.

In comparison, very little work on the Lower Jurassic palynology of Portugal has been made so far: (i) a first palynofloral data set based on dinoflagellate cysts and spores and pollen grains encompassing the lower Mesozoic of Portugal (Doubinger et al., 1970); (ii) an integrated study encompassing Triassic to Lower Jurassic miospores from Portugal (Adloff et al., 1977); and (iii) outcrop samples from Late Sinemurian to Aalenian in age studied by Davies (1985), who subdivided the succession into seven miospore zones and an equal number of dinoflagellate cyst Oppel-zones, comparing them with the eastern Canada offshore zonation established by Bujak \& Williams (1977).

In this paper, palynological and calcareous nannofossil assemblages are described and correlated in an attempt to integrate micropalaeontological data for the Pliensbachian/ Toarcian boundary in the Peniche area. Furthermore, the results of this study give additional data to support and document the GSSP definition at Ponta do Trovão section, Peniche.

\section{GEOLOGICAL SETTING}

The Lusitanian Basin (Figure 1) is located on the western margin of the Iberian Plate (Portugal), and is a marginal ocean basin which formed in the Triassic. Its orientation is NE-SW and it is approximately $300 \mathrm{~km}$ in length and $150 \mathrm{~km}$ wide,

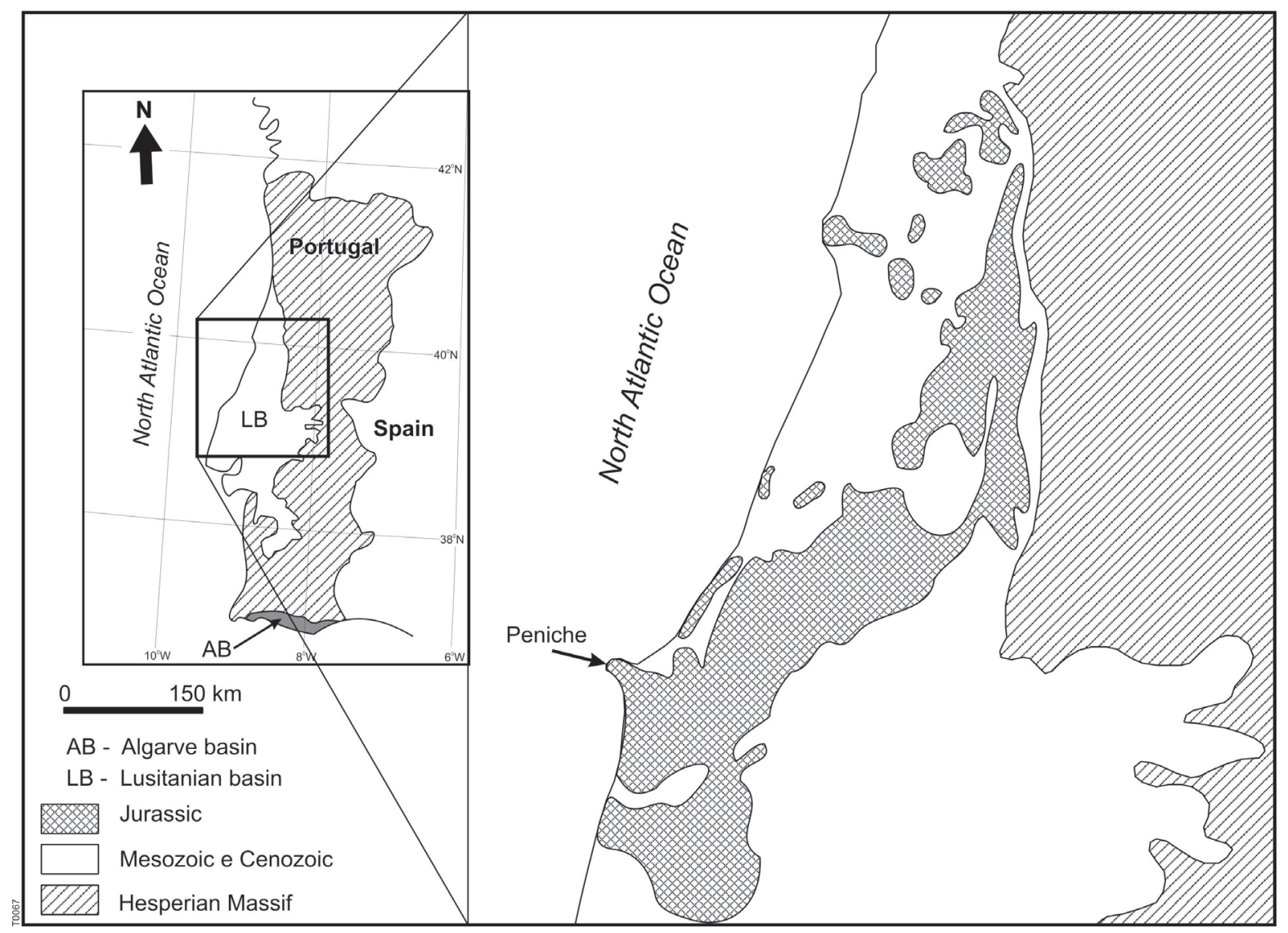

Figure 1. Location map of the study area. 

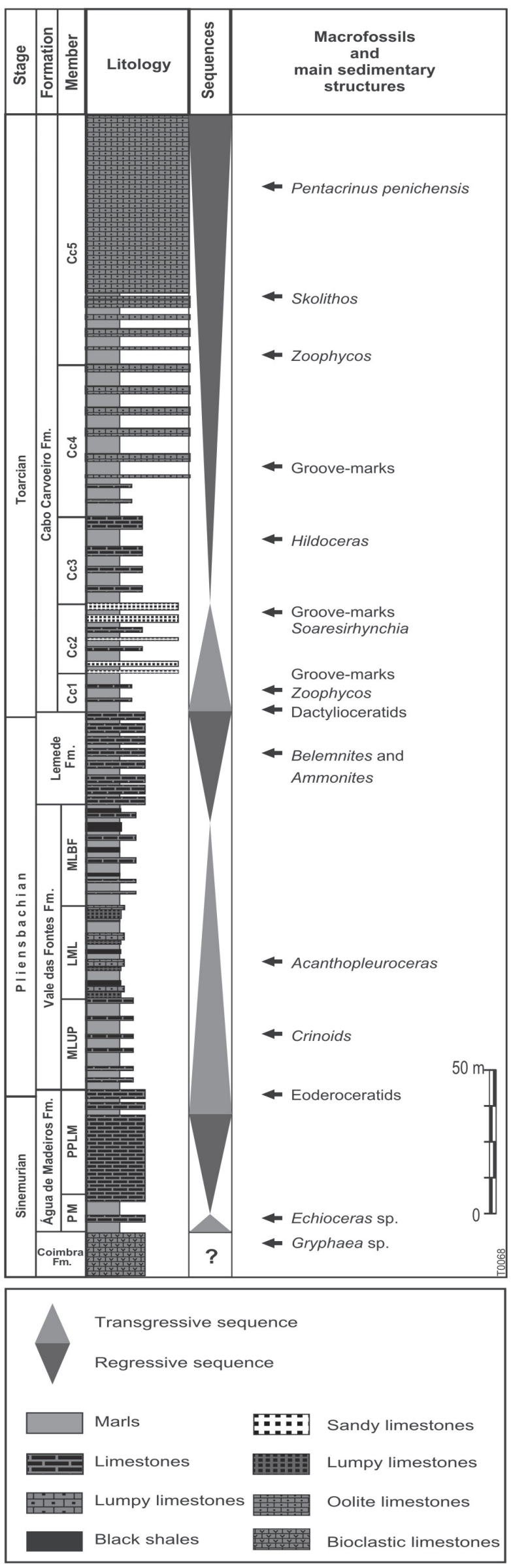

including the offshore area, with a maximum thickness of 5 $\mathrm{km}$. The sedimentary rocks range from Upper Triassic to Upper Cretaceous, and are mainly of Jurassic age, overlain by Tertiary. The Lower Jurassic is particularly well represented in the Lusitanian Basin, especially in the Peniche region, where outcrops of carbonate rocks more than $450 \mathrm{~m}$ thick are between Sinemurian and Toarcian in age (Mouterde, 1955; Wright \& Wilson, 1984; Duarte, 1995, 2003, 2004; Duarte et al. 2004b). These carbonate rocks correspond to the Coimbra, Água de Madeiros, Vale das Fontes, Lemede and Cabo Carvoeiro formations (Duarte \& Soares, 2002) (Figure 2).

During the Pliensbachian and early Toarcian, deposition in the Lusitanian Basin was controlled by homoclinal ramp dipping towards the northwest (Duarte, 1997). In Peniche area, with the exception of the Lower Sinemurian and Upper Toarcian, the whole section is well constrained by high resolution ammonite biostratigraphy. The PliensbachianToarcian boundary is represented by a limestone-marl succession, consisting of the uppermost part of the Lemede Formation and the lowermost part of Cabo Carvoeiro Formation (Figure 3). The former is composed by centimetricthick marl/decimetric-thick bioturbated limestone alternations, very rich in belemnites, ammonites, bivalves and brachiopods. The base of the Cabo Carvoeiro Formation is dominated by greyish marls and marly limestones, very rich in tiny brachiopods, belemnites, ammonites and Zoophycos.

The Peniche section was recently proposed as the main candidate for theToarcian Global Stratotype Section and Point (GSSP) (Elmi et al., 1996, 2005; Elmi, 2006; Duarte et al., 2004b). The Pliensbachian/Toarcian boundary is defined based on ammonite biostratigraphy, coinciding with the boundary between the Spinatum (Upper Pliensbachian) and Polymorphum (Lower Toarcian; Polymorphum = Tenuicostatum; Ogg, 2004) biozones (Elmi et al. 1997).

\section{SAMPLES AND METHODS}

Twelve marl samples were collected for calcareous nannofossil analysis $3 \mathrm{~m}$ below and $7 \mathrm{~m}$ above the Pliensbachian/Toarcian Stage Boundary at Ponta do Trovão (Peniche). The slides were prepared in the Petrobras Research Center (CENPES/BPA) laboratories, using the Petrobras standard methodology (Antunes, 1997; Oliveira, 1997). The slides were scanned using a Zeiss Axioplan 2 imaging microscope, at 1600X magnification; 500 fields of view were examined for each slide. The relative abundance for each species and total relative abundance estimates for each sample (Figure 4) were based on the scheme presented by Concheryo $\&$ Wise Jr. (2001). Estimates of preservation were based on the classification of Roth \& Thierstein (1972). The nannofossil

Figure 2. Schematic stratigraphy of the Peniche section (Duarte et al., 2004b). Abbreviations: PM, Polvoeira Member; PPLM, Praia da Pedra Lisa Member; MLUP, Marls and Limestones with Uptonia and Pentacrinus Member; LML, Lumpy Marls and Limestones Member; MLBF, Marls and Limestones with Bituminous Shales Member; Cc, Cabo Carvoeiro Members 1 to 5. 


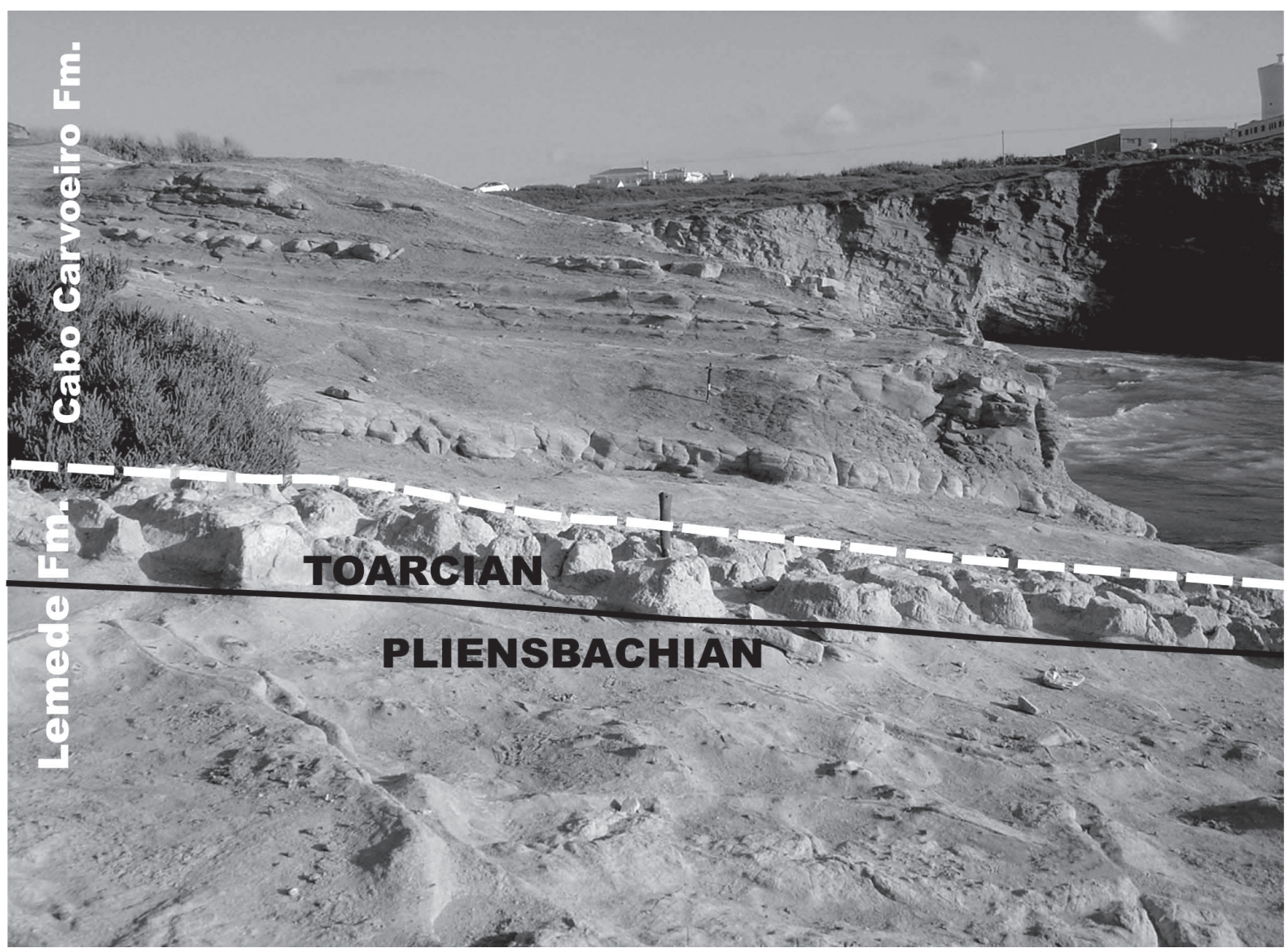

Figure 3. Pliensbachian/Toarcian Stage Boundary exposed at Ponta do Trovão (Peniche, Lusitanian Basin).

\begin{tabular}{|c|c|c|c|c|c|c|c|c|c|c|c|c|c|c|c|c|c|c|c|c|c|c|c|c|c|}
\hline \multirow[b]{2}{*}{ 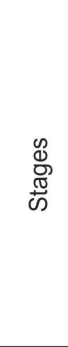 } & \multirow[b]{2}{*}{ 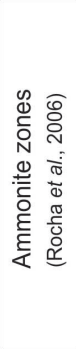 } & \multirow[b]{2}{*}{ 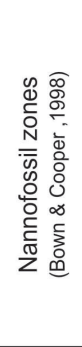 } & \multirow[b]{2}{*}{ 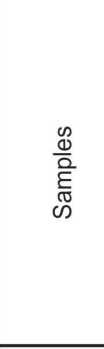 } & \multirow[b]{2}{*}{ 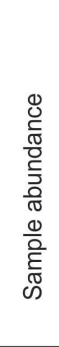 } & \multirow[b]{2}{*}{ 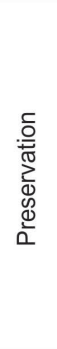 } & \multicolumn{20}{|c|}{$S P E C I E S$} \\
\hline & & & & & & 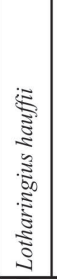 & 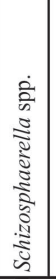 & 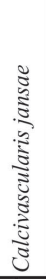 & 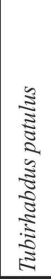 & 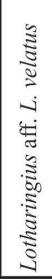 & 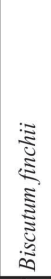 & 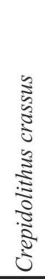 & 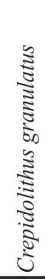 & 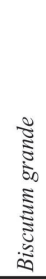 & 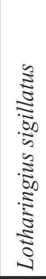 & 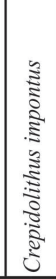 & 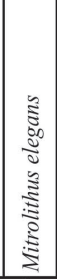 & 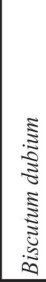 & 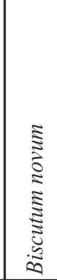 & 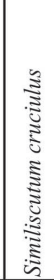 & 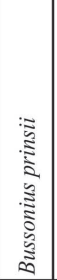 & 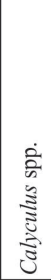 & 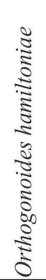 & 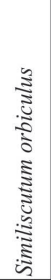 & 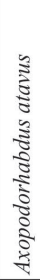 \\
\hline \multirow{5}{*}{ 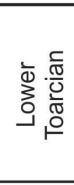 } & \multirow{5}{*}{ 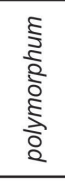 } & \multirow{10}{*}{ NJ5b } & \begin{tabular}{|l|} 
P19 \\
P15M \\
\end{tabular} & $\frac{A}{A}$ & $\mathrm{G}$ & & & & & & & & & & & 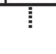 & & & 1 & & & & $\vdots$ & & \\
\hline & & & \begin{tabular}{|l|l|}
$\mathrm{P} 13 \mathrm{~B}$ \\
\end{tabular} & $A$ & $\mathrm{G} / \mathrm{M}$ & & & & & & & & i & & & 1 & & & & 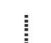 & & & & & \\
\hline & & & P5T & $\mathrm{A} / \mathrm{C}$ & $\mathrm{G} / \mathrm{M}$ & & & & & & & & & & & & & & & & & & & & 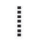 \\
\hline & & & P4 & A & $G$ & & & & & & & & & & & i & & 1 & & 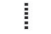 & & 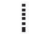 & 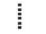 & 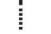 & \\
\hline & & & P1 & $\mathrm{A}$ & $\mathrm{G}$ & & & & & & & & & & & & i & & & & ! & 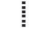 & & & \\
\hline \multirow{5}{*}{ 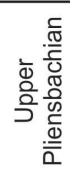 } & \multirow{5}{*}{ 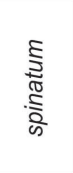 } & & PE983T & A & $G$ & & & & & & & i & & & & & & & 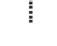 & 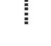 & & & & VR & \\
\hline & & & \begin{tabular}{|l} 
PE979 \\
PE975
\end{tabular} & $\frac{A}{A}$ & $G$ & & & & & & & 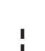 & & & & ! & $\vdots$ & & 1 & & & & & $\mathrm{R}$ & \\
\hline & & & \begin{tabular}{|l} 
PE975 \\
PE965
\end{tabular} & A & $\mathrm{G}$ & & & & & & & & & & & & & & & & & & & $\mathrm{F}$ & \\
\hline & & & $\begin{array}{l}\text { PE951 } \\
\end{array}$ & A & G & & & & & & & & & & ! & & i & & & & & & & C & \\
\hline & & & $\begin{array}{l}\text { PE947 } \\
\end{array}$ & A & G & & & & & & & & & & & & & & & & & & & & \\
\hline
\end{tabular}

\begin{tabular}{l}
\hline Relative abundance of species \\
VR =Very rare $(1$ specimen per $201-500$ fields of view) \\
$R=$ Rare $(1$ specimen per $51-200$ fields of view) \\
$F=$ Frequent $(1$ specimen per $11-50$ fields of view $)$ \\
$C=$ Common $(1$ specimen per $2-10$ fields of view) \\
$A=$ Abundant $(1-10$ specimens per fields of view) \\
The same definitions were used to estimate total \\
abundance of each sample.
\end{tabular}

Preservation $\mathrm{M}=$ Moderate. Dissolution and overgrowth are evident

Up to $25 \%$ of the specimens cannot be identified to species level.

$G=$ Good. Little dissolution and overgrowth

Diagnostic characteristics are preserved and all specimens are identified

Figure 4. Calcareous nannofossil distribution in the studied interval. 

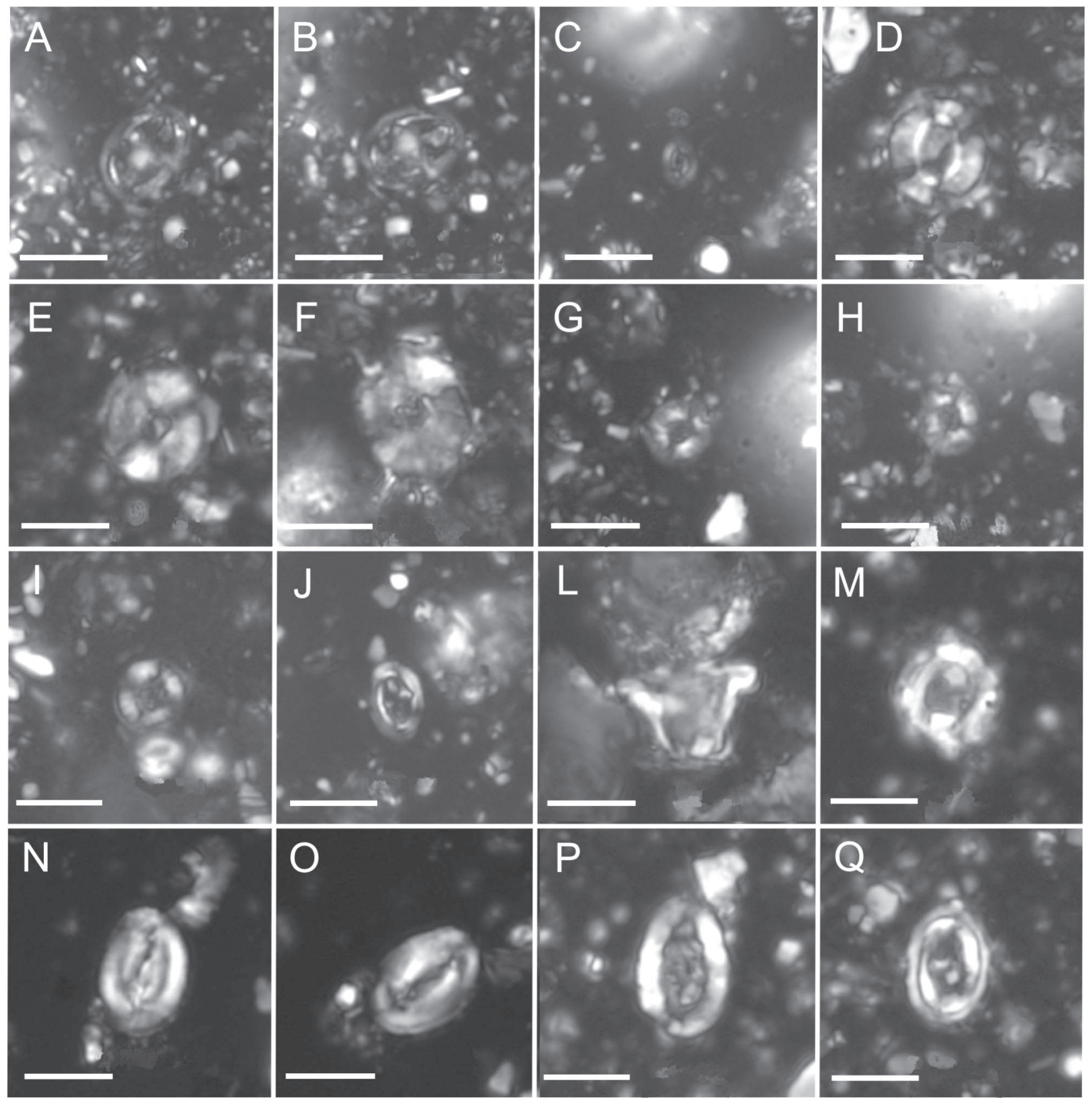

Figure 5. Calcareous nannofossil species observed in the studied interval (cross polarized light). A-B, Axopodorhabdus atavus (same specimen, A at $0^{\circ}$, B at $45^{\circ}$ ); C, Biscutum dubium; D, Biscutum grande; E-F, Biscutum finchii (different specimens); G-I, Biscutum novum (G-H, same specimen, $\mathbf{G}$ at $0^{\circ}, \mathbf{H}$ at $45^{\circ}$; I, different specimen); J, Bussonius prinsii; L-M, Calyculus sp. (different specimens, L, side view; $\mathbf{M}$, top view); $\mathbf{N}-\mathbf{O}$, Crepidolithus crassus (same specimen, $\mathbf{N}$ at $0^{\circ}, \mathbf{O}$ at $45^{\circ}$ ); $\mathbf{P}$, Crepidolithus granulatus; $\mathbf{Q}$, Crepidolithus impontus. Scale bar $=5 \mu \mathrm{m}$.

photos were obtained with a Zeiss AxioCam MRc digital camera using the Axionvision 4 software.

Thirteen samples were examined for palynological content. The samples were processed using conventional techniques (e.g. Phipps \& Playford, 1984; Wood et al., 1996) for the retrieval and concentration of palynomorphs. Roughly $30-40 \mathrm{~g}$ of sample were broken into pea-sized fragments, which were immersed for ca. 2 hours in hydrochloric acid (32\%), and then in hydrofluoric acid (ca. 40\%) for 22 hours for the dissolution of carbonates and silicates respectively. The resultant residue was then oxidized for 10 minutes with concentrated nitric acid. Any remaing mineral matter was removed by means of heavyliquid separation (zinc chloride, S.G. 1.95-2.00), and a few drops of the definitive residue were mounted on glass slides as permanent strew mounts in a polyester resin ("Entellan"). Optical microscopy was performed using Nikon and Zeiss Axioplan microscopes; the latter was utilized for photomicrography (with Kodak T-Max $10035-\mathrm{mm}$ film). 


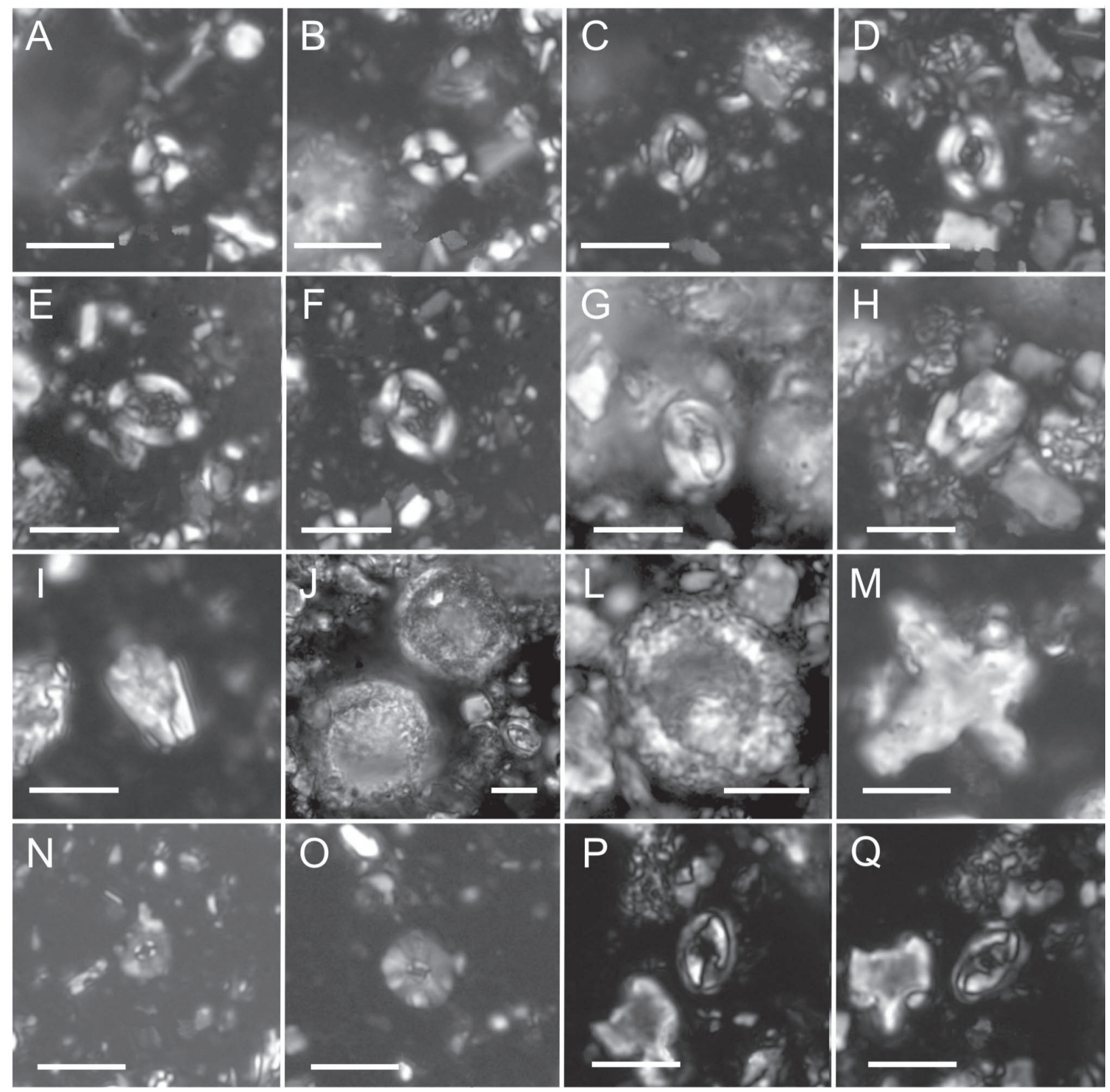

Figure 6. Calcareous nannofossil species observed in the studied interval (cross polarized light). A-B, Lotharingius hauffii (different specimens); C-D, Lotharingius sigillatus (different specimens); E-F, Lotharingius aff. L. velatus (same specimen, $\mathbf{E}$ at $0^{\circ}, \mathbf{F}$ at $45^{\circ}$ ); $\mathbf{G}$, Mitrolithus elegans; H-I, Calcivascularis jansae (different specimens); J-L, Schiszosphaerella sp. (different specimens); M, Orthogonoides hamiltoniae; N, Similiscutum orbiculus; $\mathbf{O}$, Similiscutum cruciulus; $\mathbf{P}-\mathbf{Q}$, Tubirhabdus patulus (same specimen, $\mathbf{P}$ at $0^{\circ}, \mathbf{Q}$ at $45^{\circ}$ ). Scale bar $=5 \mu \mathrm{m}$.

\section{MICROPALEONTOLOGICAL DATA}

\section{Calcareous nannofossil assemblages}

All the samples yielded common to abundant assemblages that were moderately to well-preserved. Thirteen genera and 18 species (Figures 4 to 6 ) were identified. The genus Schizosphaerella, along with Lotharingius hauffii and Calcivascularis jansae, dominate the assemblages, which is also characterized by the continuous presence of Biscutum finchii, B. grande, Crepidolithus crassus, C. granulatus, Lotharingius aff. L. velatus and Tubirhabdus patulus. Biscutum dubium, B. novum, Bussonius prinsii, Calyculus spp., Mitrolithus elegans, Orthogonoides hamiltoniae, Similiscutum cruciulus, and Similiscutum orbiculus are sporadically present and range in abundance from very rare to few. A few specimens of Axopodorhabdus atavus have been identified from one sample (P5T). Present from the bottom of the succession, the relative abundance of Crepidolithus impontus and Lotharingius sigillatus increase upwards, in particular that of $L$. sigillatus.

\section{Palynological assemblages}

A rich, poorly-preserved palynoflora were extracted from the Upper Pliensbachian/Lower Toarcian deposits of the 


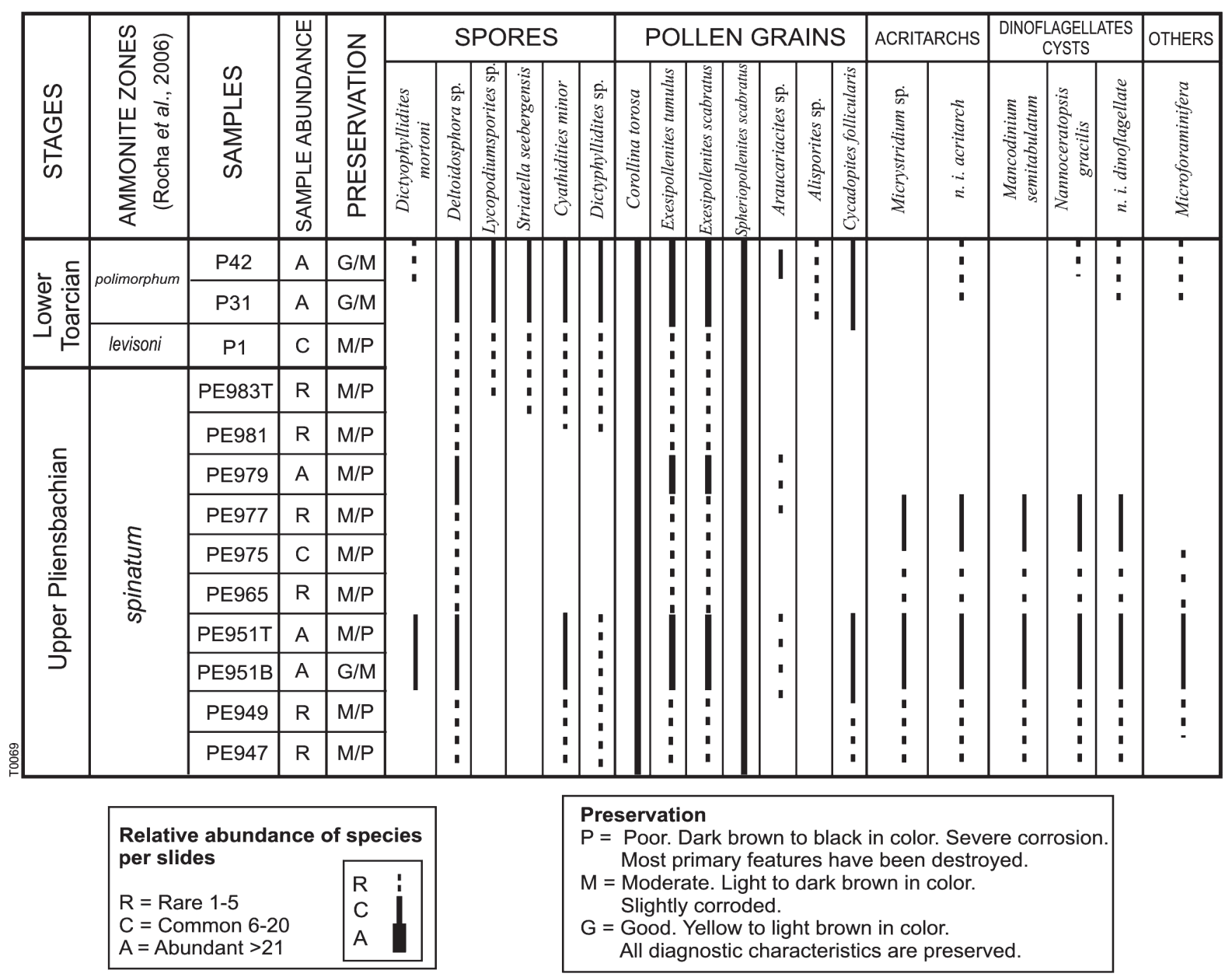

Figure 7. Distribution of palynomorphs in the studied section.

Lusitanian Basin in the Peniche area. Some of these samples are either barren or contain badly preserved palynomorphs. From the productive samples, 30 species of spores, pollen grains, dinoflagellate cysts, acritarchs, and organic microforaminifer inner walls (foraminifer linings) were identified (Figures 7 and 8). Terrestrial palynomorphs (spores and pollen grains) dominate the assemblage; also the presence of the dinoflagellate cysts is significant, mainly at the lower part of the section (corresponding to the Upper Pliensbachian). The most common spores belong to the Dictyophyllidites, and Deltoidospora genera, and the pollen grains are dominated by Corollina torosa, Spheripollenites scabratus, Exesipollenites scabratus, and others small inaperturate pollen grains. Additionally, dinoflagellate cysts related to the Mancodinium and Nannoceratopsis genera are important assemblage elements, and are better represented semi-quantitatively in the lower portion of the section studied.

The palynoflora is characterized by moderate preservation in the lower part of the section and by higher proportions of marine elements when compared with the upper part (Lower Toarcian). However, the palynoflora is better preserved and the terrestrial influence is stronger, in the upper part of the section, as evidenced by increased abundance of
Exesipollenites, and Spheripollenites pollen grains.

The recovered palynoflora is dominated by gymnosperm pollen grains, in particular Corollina torosa (the most abundant species), together with Spheripollenites and Exesipollenites (Figure 7). Also represented are small, smooth and apiculate trilete spores (Dictyophyllidites, Deltoidospora, and Cyathidites), together with dinoflagellate cysts (Mancodinium and Nannoceratopsis). Other marine microplankton (acritarchs and microforaminifers lining) are common, although they do not occur in all samples. Bisaccate and monosulcate pollen grains are rare components of the assemblage.

Palynological evidence also indicates a strong continental influence on the depositional environment testified by the almost exclusively and continual presence of woody organic material in the residue.

\section{REMARKS}

The Upper Pliensbachian/Lower Toarcian portion of the biostratigraphic scheme proposed by Bown \& Cooper (1998) and Mattioli \& Erba (1999) and the zonal markers utilized to define their calcareous nannofossil zone and subzone boundaries can be observed in Figure 9. They 


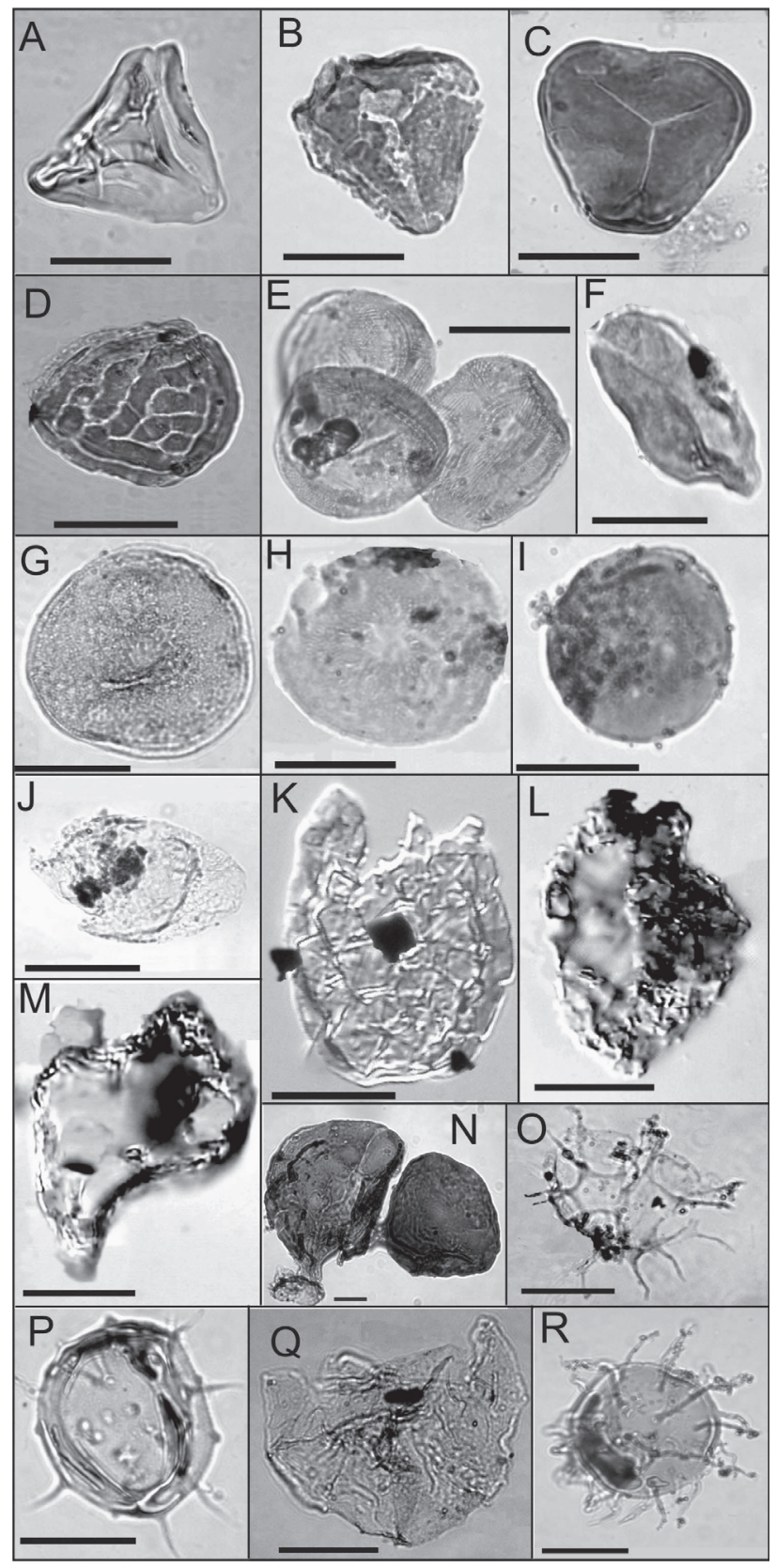

Figure 8. Terrestrial (A-J) and marine (K-R) palynomorphs in the studied section. A, Dictyophyllidites mortonii; B, Deltoidospora sp.; C, Cyathidites minor; D, Striatella seebergensis; E, Corollina torosa; F, Cycadopites follicularis; G, Exesipollenites tumulus; $\mathbf{H}$, Exesipollenites scabratus; I, Spheripollenites scabratus; J, Alisporites spp.; K, Mancodinium semitabulatum; L, Nannoceratopsis gracilis; M, Nannoceratopsis gracilis; N, microforaminifer; $\mathbf{O}$, Dinoflagellate $\mathrm{n}$. id.; $\mathbf{P}$, Micrhystridium sp.; $\mathbf{Q}$, Dinoflagellate n. id.; R, Acritarch $\mathrm{n}$. id. Scale bar $=15 \mu \mathrm{m}$.

are correlated with the biohorizons and calcareous nannofossil zones recognized in the Basque-Cantabrian area by Perilli et al. (2004), calibrated in respect of the ammonite subzones. In Northwest of Europe and Italy and south of France, the Pliensbachian/Toarcian Boundary lies within the Lotharingius hauffii Zone and more specifically within the NJ5b Crepidolithus impontus Subzone of Bown \& Cooper (1998) and coinciding with the NJT5a Biscutum finchii/NJT5b Lotharingius sigillatus Subzone boundary of Mattioli \& Erba (1999). In the Basque-Cantabrian area, the successive First Common Occurrence (FCO) of Lotharingius hauffii and the Last Common Occurrence (LCO) of Calcivascularis jansae allow the division of the NJ5 Lotharingius hauffii Zone into three portions, and the Pliensbachian/Toarcian Stage Boundary is positioned between the FCO of Lotharingius hauffii and the LCO of Calcivascularis jansae. Since the FCO of $L$. hauffii roughly approaches the NJ5a/NJ5b Subzone boundary of Bown \& Cooper (1998), the Pliensbachian/Toarcian Stage Boundary lies within the NJ5b Subzone, in the Basque-Cantabrian area.

The presence of Crepidolithus impontus and the absence of Carinolithus superbus, places the Pliensbachian/Toarcian Boundary, exposed in the reference section of Peniche, in the NJ5b Subzone. With respect to the scheme proposed by Mattioli \& Erba (1999) it lies within the NJT5b Lotharingius sigillatus Subzone, because Lotharingius sigillatus is present from the bottom of the interval sampled. However, in the Basque-Cantabrian area the first specimen of Lotharingius sigillatus is present from the spinatum ammonite zone.

The common and continuous presence of Calcivascularis jansae, along with the presence of $B$. grande, support a Tethyan affinity for the calcareous nannofossil assemblages recovered from the Pliensbachian/ Toarcian transition sampled at Peniche. In particular, Calcivascularis jansae is the most striking Tethyan marker (Bown, 1987; Bown \& Cooper, 1998).

Palynostratigraphic biozonation schemes for the European Lower Jurassic interval are profuse (e.g. Davey \& Riley, 1978; Morbey, 1978; Wille \& Gocht, 1979; Bjaerke, 1980; Woollam \& Riding, 1983; Davies, 1983, 1985; Riding, 1984a, 1984b; Williams \& Bujak, 1985; Feist-Burkhardt \& Wille, 1992; Riding \& Ioannides, 1996; Bucefallo-Palliani \& Riding, 1997, 2003; Koppelhus \& Hansen, 2003; Poulsen \& Riding, 2003). Most of them are based on dinoflagellate cysts due to their abundance in the Jurassic marine deposits of Europe. In consequence, there are fewer published schemes based exclusively on spores and pollen grains, or utilizing a combination of these groups.

The palynoflora here identified are characterized by the dominance of relatively long-ranging species; hence, it was not possible to fit it into any biozone scheme available. However, some considerations could be drawn based on some species and their relative abundance.

The most conspicuous component of the palynoflora is the presence in almost all productive samples of Nannoceratopsis gracilis which, ranges from the late Pliensbachian to Bajocian (see compiled range charts in Bucefallo-Palliani \& Riding, 2003). This specie has its inception in late Pliensbachian biozones of some palynological European schemes (e.g. Feist-Burkhardt \& Wille, 1992; Bucefallo-Palliani \& Riding, 2000; Poulsen, 1996). Davies (1985) correlated the first occurrence of $N$. gracilis to the Luehndea sp. A biozone of his dinoflagellate cyst scheme. He considered this palynozone to encompass 


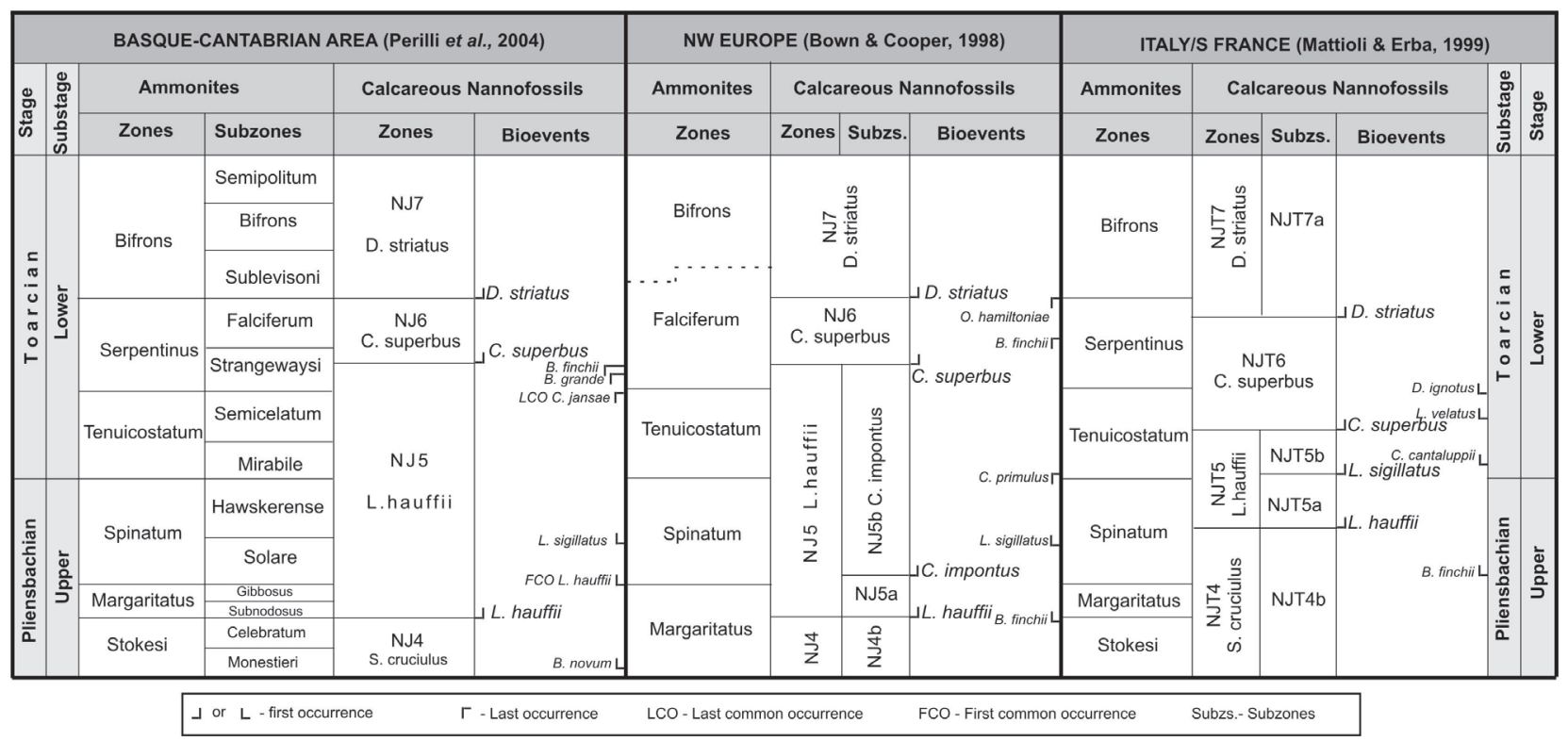

Figure 9. Calcareous nannofossil zonal correlation between Basque Cantabrian area, Northwest Europe and Italy and South France (modified from Perilli et al., 2004).

the Spinatum and Tenuicostatum ammonite zones, and is indicative of uppermost Pliensbachian to lower Toarcian sediments. Furthermore Van Helden (1977) and Riding et al. (1999), report that $N$. gracilis has a wide geographical distribution in the Northern Hemisphere. The occurrence of Mancodinium semitabulatum, is considered as ranging from Pliensbachian to Bajocian (Bucefallo-Palliani \& Riding, 2003), having its inception in the Early Pliensbachian palynozonal schemes of Europe (Feist-Burkhardt \& Wille, 1992; Poulsen, 1996).

With respect to the miospores, strong correlation exists between the assemblage identified here and assemblage zones defined for the Early Jurassic sediments (e.g. Davies, 1985; Koppelhus \& Dam, 2003), where biozones characterized by abundance or acmes of Corollina torosa, and Spheripollenites scabratus are defined and the late Pliensbachian/early Toarcian age ascribed.

Subsequently, besides the non definition of a specific palynozone, the assemblage here identified is in accordance with the attributed age recognized by the nannofossil and ammonite methods.

Regarding the palaeoenvironment, the palynoflora suggests the prevalence of warm climatic conditions during deposition, evidenced by the high content of Corollina toros $a$, pollen grains produced by the xerophythic (droughtresistant) and thermophythic Cheirolepidaceae, which are considered to reflect warm and arid conditions (Vakhrameev, 1982, 1991). In addition, the presence of dinoflagellates cysts, organisms that currently form a major part of the ocean plankton (Armstrong \& Brasier, 2005) together with pollen grains and terrestrial macerals confirms that it occurred in a marine relatively shallow and nearshore environment with a large input of terrigenous material (Herngreen et al., 2000); and that this terrestrial influence increase upward in the section.

\section{FINAL CONSIDERATIONS}

The calcareous nannofossil and palynomorph results obtained throughout the Pliensbachian/Toarcian boundary, in the Ponta do Trovão area in Peniche, allow several interpretations regarding the micropaleontological assemblages, biostratigraphy, geological ages, palaeoenvironment and Tethys influence, summarized in the Figure 10. The studied calcareous nannofossil assemblages are abundant, diversified and well preserved, allowing relative abundance estimation and revealing that Schizosphaerella spp., Lotharingius hauffii and Calcivascularis jansae dominate the assemblages. Crepidolithus impontus and Lotharingius sigillatus are rare at the base of studied section increasing in abundance upwards. In contrast, the palynology assemblage is poor, low diversified and badly preserved, dominated by gymnosperms (Cupressaceae, Taxodiaceae and Taxaceae) with low frequency of spores and dinoflagellate cysts, with rare bissacate pollen grains.

Regarding biostratigraphy and age, the calcareous nannofossils present good definition. Bown \& Cooper (1998) defined the NJ5b Subzone as an interval between the FO of Crepidolithus impontus to the FO of Carinolithus superbus. As the former is present and the latter is absent, the analyzed interval places in the NJ5b Crepidolithus impontus Subzone. With respect to the scheme proposed by Mattioli \& Erba (1999), all the samples analyzed for calcareous nannofossils lie within the NJT5b Lotharingius sigillatus Subzone. Using the Perilli et al. (2004) scheme the studied section corresponds to the NJ5 Zone. Ogg (2004), using the von Salis (1998) compilation, placed the Pliensbachian/Toarcian boundary into the NJ5b, as is indicated herein. Besides, this author indicated an absolute age of $183.0 \pm 1.5 \mathrm{Ma}$ to this Stage Boundary. Nevertheless, it is not possible to fit the palynoflora into any biozone scheme because it is dominated by long-ranging species. 


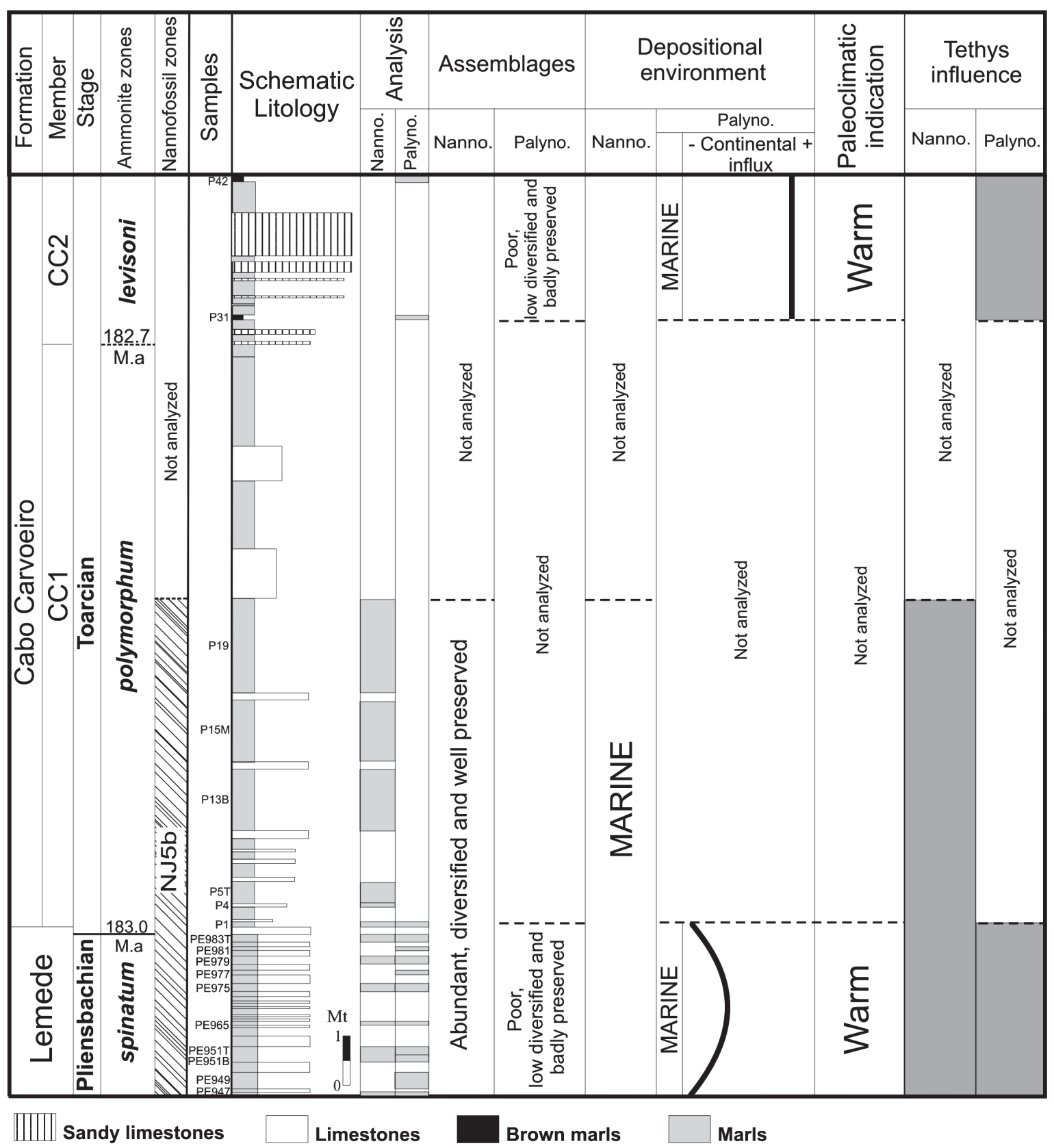

Figure 10. Calcareous nannofossil and palynomorph data integration. Ammonite zones from Rocha et al. (1996); calcareous nannofossil zones based on Bown \& Cooper (1998) scheme; lithostratigraphy from Duarte et al. (2004b) and absolute ages from Ogg (2004). Abbreviations: nanno, calcareous nannofossils; palyno, palynomorphs.

Based on the calcareous nannofossil and, chiefly, palynological analysis, it is possible to suggest that the depositional environment was predominately marine, with gradual increasing of continental influence upward to the studied section top. These conclusions are supported by the augment of the terrestrial debris and the spores and pollen grains content towards the top of the section. In addition, the domination of rimulates and inaperturate pollen grains suggest the prevalence of warm climatic conditions during the Pliensbachian/Toarcian boundary.

Furthermore, the Tethyan influence can be demonstrated by the presence of some Tethyan marker fossils recovered from the Pliensbachian-Toarcian transition sampled at Peniche. According to Bown \& Cooper (1998), the Lower Jurassic nannofloras from western Tethys are characterized by the abundant occurrence of Calcivascularis jansae and other endemic forms, included Biscutum grande. In Peniche, C. jansae is abundant in all samples and Biscutum grande is frequent in some samples, mainly in the Toarcian, supporting a Tethyan affinity for the calcareous nannofossil assemblages. In the palynomorph assemblages Tethyan influence is indicated by the presence of Mancodinium semitabulatum and Nannoceratopsis gracilis (BucefalloPalliani \& Riding, 2003). 


\section{ACKNOWLEDGMENTS}

We thank Petrobras for the financial and technical support, to Adelino T. Dias and Heriberto V. Santos for helping with illustrations and two anonymous referees, whose constructive comments greatly improved this paper. This paper was a contribution to the XIX Congresso Brasileiro de Paleontologia/VI Congresso Latino-americano de Paleontologia, held in August, 2005, in Aracaju (SE, Brazil).

\section{REFERENCES}

Adloff, M.C.; Doubinger, J. \& Palain, C. 1977. Contribution à la palynologie du Trias et du Lias inférieur du Portugal Grès de Silves du Nord du Tage. Comunicações dos Serviços Geológicos de Portugal, 58(1974):91-144.

Antunes, R.L. 1997. Introdução ao estudo dos nanofósseis calcários. Série didática UFRJ, Rio de Janeiro, 115 p.

Armstrong, H.A. \& Brasier, M.D. 2005. Microfossils. Part 3: Organic-walled microfossils. Blackwell Publishing, p. 71-125.

Bjaerke, T. 1980. Mesozoic palynology of Svalbard IV. Toarcian dinoflagellates from Spitsbergen. Palynology, 4:57-77.

Bown, P.R. 1987. Taxonomy, evolution, and biostratigraphy of Late Triassic-Early Jurassic calcareous nannofossils. The Palaeontological Association, Special Papers in Paleontology v. 38, 118 p.

Bown, P.R. \& Cooper, M.K.E. 1998. Jurassic. In: P.R. Bown (ed.) Calcareous nannofossil biostratigraphy, Chapman \& Hall, p. 3485.

Bown, P.R.; Cooper, M.K.E. \& Lord, A.R. 1988. A calcareous nannofossil biozonation scheme for the early to mid Mesozoic. Newsletters on Stratigraphy, 20(2):91-114.

Bucefallo-Palliani, R. \& Riding, J.B. 1997. Influence of paleoenvironmental change on dinoflagellate cyst distribution. An example from the Lower and Middle Jurassic of Quercy, southwest France. Bulletin du Centre de Recherches Elf Exploration Production, 21:107-123.

Bucefallo-Palliani, R. \& Riding, J.B. 2000. A palynological investigation of the Lower and lowermost Middle Jurassic strata (Sinemurian to Aalenian) from North Yorkshire, UK. Proceedings of the Yorkshires Geological Society, 53:1-16.

Bucefallo-Palliani, R. \& Riding, J.B. 2003. Biostratigraphy, provincialism and evolution of European early Jurassic (Pliensbachian to early Toarcian) dinoflagellate cysts. Palynology, 27:179-214.

Bujak, J. \& Williams, G. 1977. Jurassic palynostratigraphy of offshore eastern Canada. In: F.M. Swain (ed.) Stratigraphic micropaleontology of Atlantic Basin and borderlands, Elsevier, p. 321-339.

Concheryo, A. \& Wise, S.W., Jr. 2001. Jurassic calcareous nannofossil from prerift sediments drilled during ODP Leg 173, Iberia Abyssal Plain, and their implications for rift tectonics. In: M.-O. Beslier; R.B. Whitmarsh; P.J. Wallace \& J. Girardeau (eds.) Proceedings of the Ocean Drilling Program, Scientific Results, 173, 1-24. Available at <http://www-odp.tamu.edu/ publications/173_SR/VOLUME/CHAPTERS/ SR173 07.PDF>. Acessed in March 16, 2004.

Davey, R.J. \& Riley, L.A. 1978. Late and Middle Jurassic dinoflagellate cysts. In: B. Thsu (ed.) Distribution of biostratigraphically diagnostic dinoflagellate cysts and miospores from the Northwest European continental shelf and adjacent areas, Continental Shelf Institute Publication, p. 3145.

Davies, E.H. 1983. The dinoflagellate Oppel-zonation of the JurassicLower Cretaceous sequence in the Sverdrup Basin, Artic Canada. Geological Survey of Canada Bulletin, 59 p. (Bulletin 359).

Davies, E.H. 1985. The miospore and dinoflagellate cyst oppelzonation of the Lias of Portugal. Palynology, 9:105-132.

Doubinger, J.; Adloff, M.C. \& Palain, C. 1970. Nouvelles precisions stratigraphiques sur la série de base du Mesozoique portugais. Comptes Rendus de l'Academie de Sciences, 270:1700-1772.

Duarte, L.V. 1995. O Toarciano da bacia Lusitaniana. Estratigrafia e evolução sedimentogenética. Departamento de Ciências da Terra, Universidade de Coimbra, Tese de Doutoramento, 349 p.

Duarte, L.V. 1997. Facies analysis and sequential evolution of the Toarcian-Lower Aalenian series in the Lusitanian Basin (Portugal). Comunicações do Instituto Geológico e Mineiro, 83:65-94.

Duarte, L.V. 2003. Variações de fácies, litostratigrafia e interpretação seqüencial do Liássico médio e superior ao longo da transversal Tomar-Peniche (Portugal). Ciências da Terra (UNL), 5:A53-A56 (CD-ROM).

Duarte, L.V. 2004. The geological heritage of the Lower Jurassic of Central Portugal: selected sites, inventory and main scientific arguments. Rivista Italiana di Paleontologia i Stratigrafia, 110:381-387.

Duarte, L.V. \& Soares, A.F. 2002. Litostratigrafia das séries margocalcárias do Jurássico inferior da bacia Lusitânica (Portugal). Comunicações do Instituto Geológico e Mineiro, 89:15-134.

Duarte, L.V.; Perilli, N.; Dino, R.; Rodrigues, R. \& Paredes. R. 2004a. Lower to Middle Toarcian from the Coimbra region (Lusitanian Basin, Portugal): sequence stratigraphy, calcareous nannofossils and stable-isotope evolution. Rivista Italiana di Paleontologia e Stratigrafia, 110:115-127.

Duarte, L.V.; Wright, V.P.; Fernandéz-Lopéz, S.; Elmi, S.; Krautter, M.; Azerêdo, A.C.; Henriques, M.H.; Rodrigues, R. \& Perilli, N. 2004b. Early Jurassic carbonate evolution in the Lusitanian Basin: facies, sequence stratigraphy and cyclicity. In: IAS MEETING OF SEDIMENTOLOGY, 23, 2004. Field Trip Guide Book, Coimbra, 1:45-71.

Elmi, S. 2006. Pliensbachian/Toarcian boundary: the proposed GSSP of Peniche (Portugal). Volumina Jurassica, 4:5-16.

Elmi, S.; Mouterde, R.; Rocha, R. \& Duarte, L.V. 1996. La limite Pliensbachien-Toarcien au Portugal: intérèt de la coupe de Peniche. Aalenews, 6:33-35.

Elmi, S.; Rulleau, L.; Gabilly, J. \& Mouterde, R. 1997. Toarcien. Bulletin du Centre de Recherches Elf Exploration Production, 17:25-36.

Elmi, S.; Duarte, L.V.; Mouterde, R.; Rocha, R.B. Soares, A.F. 2005. The Peniche Section (Portugal) candidate to the Toarcian Global Stratotype Section and Point (GSSP). INTERNATIONAL SUBCOMMISSION ON JURASSIC STRATIGRAPHY. Toarcian Working Group. Field Trip Meeting. Centro de Investigação em Geociências Aplicadas da Universidade de Nova Lisboa and Centro de Geociências da Universidade de Coimbra. 51 p.

Feist-Burkhardt, S. \& Wille, W. 1992. Jurassic palynology in southwest Germany - state of the art. Cahiers de Micropaléontologie, 7:141-156.

Hamilton, G.B. 1977. Early Jurassic calcareous nannofossils from Portugal and their biostratigraphic use. Eclogae Geologicae Helvetiae, 70:575-597.

Hamilton, G.B. 1979. Lower and Middle Jurassic calacareous nannofossils from Portugal. Eclogae Geologicae Helvetiae, 72:1-17.

Herngreen, G.F.W.; Kerstholt, S.J. \& Munsterman, D.K. 2000. Callovian-Ryazanian ('Upper Jurassic') palynostratigraphy of the Central North Sea Graben and Vlieland Basin, the Netherlands. 
Mededelingen NITG-TNO, 63:1-100.

Kaenel, E.; Bergen, J.A. \& von Salis Perch-Nielsen, K. 1996. Jurassic calcareous nannofossil biostratigraphy of Western Europe. Compilation of recent studies and calibration of bioevents. Bulletin de la Société Géologique de France, 167(1):15-28.

Koppelhus, E.B. \& Dam, G. 2003. Palynostratigraphy and palaeoenvironments of the Rævekløft, Gule Horn and Ostreaelv Formations (Lower-Middle Jurasic), Neill Klinter Group, Jameson Land, East Greenland. In: The Jurassic of Denmanrk and Greenland, Geological Survey of Denmark and Greenland, p. 723-775 (Bulletin 1).

Koppelhus, E.B. \& Hansen, C.F. 2003. Palynostratigraphy and palaeoenvironment of the Middle Jurassic Sortehat Formation (Neil Klinter Group), Jameson Land, East Greenland. In: The Jurassic of Denmanrk and Greenland, Geological Survey of Denmark and Greenland, p. 777-811. (Bulletin 1)

Mattioli, E. \& Erba, E. 1999. Synthesis of calcareous nannofossil events in the Tethyan Lower and Middle Jurassic successions. Rivista Italiana di Paleontologia e Stratigrafia, 105(3):343-376.

Morbey, S.J. 1978. Late Triassic and Early Jurassic subsurface palynostratigraphy in northwestern Europe. Palinologia, 1:355365.

Mouterde, R. 1955. Le Lias de Peniche. Comunicações dos Serviços Geológicos de Portugal, 36:87-115.

Ogg, J.G. 2004. The Jurassic Period. In: F.M. Gradstein ; J.C. Ogg \& A.G. Smith (eds.) A Geological Timescale 2004, Cambridge University Press, 307-343.

Oliveira, L.C.V. 1997. Arcabouço estratigráfico do AlboMaastrichtiano da bacia de Campos: Um estudo com base em nanofósseis calcários e suas relações com marcos elétricos estratigráficos e a estratigrafia química. Instituto de Geociências, Universidade Federal do Rio Grande do Sul, Dissertação de Mestrado, $181 \mathrm{p}$.

Perilli, N. 1999. Calibration of early-middle Toarcian nannofossil in two expanded and continuous sections from the BasqueCatabrian area (Northern Spain). Revista Española de Micropaleontología, 31(3):393-401.

Perilli, N. 2000. Calibration of early-middle Toarcian nannofossil events based on high-resolution ammonite biostratigraphy in two expanded sections from the Iberian Range (East Spain). Marine Micropaleontology, 39:293-308.

Perilli, N. \& Comas-Rengifo, M.J. 2002. Calibration of the Pliensbachian calcareous nannofossil events in two ammonitecontrolled sections from northern Spain (Basque-Cantabrian Area). Rivista Italiana di Paleontologia e Stratigrafia, 108(1):133-152.

Perilli, N. \& Duarte, L.V. 2003. Dating of the Toarcian succession from the Lusitanian Basin based on calcareous nannofossil. Ciências da Terra (UNL), 5:A122-A125 (CD-ROM).

Perilli, N. \& Duarte, L.V. 2006. Toarcian nannobiohorizons from Lusitanian Basin (Portugal) and their calibration against ammonite zones. Rivista Italiana di Paleontologia i Stratigrafia, 112(3):417434.

Perilli, N.; Comas-Rengifo, M.J. \& Goy, A. 2004. Calibration of the Pliensbachian-Toarcian calcareous nannofossil zone boundaries based on ammonites (Basque-Cantabrian area, Spain). Rivista Italiana di Paleontologia e Stratigrafia, 110(1):97-107.

Phipps, D. \& Playford, G. 1984. Laboratory techniques for extraction of palynomorphs from sediments. Papers of the Department of Geology, University of Queensland, 11(1):1-23.

Poulsen, N.E. 1996. Dinoflagellate cysts from marine Jurassic deposits of Denmark and Poland. American Association of Stratigraphic Palynologists Contributions Series, 31:1-227.

Poulsen, N.E. \& Riding, J.B. 2003. The Jurassic dinoflagellate cyst zonation of Subboreal Northwest Europe. Geological Survey of Denmark and Greenland Bulletin, 1:115-144.
Riding, J.B. 1984a. Dinoflagellate range top biostratigraphy of the uppermost Triassic to lowermost Cretaceous of northwest Europe. Palynology, 8:195-210.

Riding, J.B. 1984b. A palynological investigation of Toarcian to early Aalenian strata from the Blea Wyke area. Ravenscar, North Yorkshires. Proceedings of the Yorkshire Geological Survey, 45:109-122.

Riding, J.B. \& Ioannides, N.S. 1996. A review of Jurassic dinoflagellate cyst biostratigraphy and global provincialism. Bulletin de la Société Géologique de France, 167:3-14.

Riding, J.B.; Fedorova, V.A. \& Ilyina, V.I. 1999. Jurassic and Lowermost Cretaceous dinoflagellate cyst biostratigraphy of the Russian Platform and Northern Siberia, Russia. American Association Stratigraphers Palynologists Contributions Series, 179 p. (Contribution 36)

Roth, P.H. \& Thierstein, H. 1972. Calcareous nannoplankton. Leg 14 of the Deep Sea Drilling Project. Washington, US Government Printing Office, p. 421-485 (Reports DSDP 14).

Rocha, R.B.; Marques, B.L.; Kullberg, J.C.; Caetano, P.S.; Lopes, C.; Soares, A.F.; Duarte, L.V.; Marques, J.F. \& Gomes, C.R. 1996. The 1st and 2nd rifting phases of the Lusitanian Basin: stratigraphy, sequence analysis and sedimentary evolution. Project Milupobas, Comission for the European Communities, Lisboa, 4v.

Vakhrameev, V.A. 1982. Classopollis pollen as an indicator of Jurassic and Cretaceous climate. International Geological Review, 24:1190-1196.

Vakhrameev, V.A. 1991. Jurassic and Cretaceous floras and climates of the Earth. Cambridge, Cambridge University Press, 318 p.

Van Helden, B.G.T. 1977. Correlation of microplankton assemblages with ammonite faunas from the Jurassic Wilkie Point Formation, Prince Patrick Island, District of Franklin. Geological Survey of Canada, 77(1B):163-171.

Von Salis, K. 1998. Calcareous nannofossils [column for Triassic and Cretaceous charts, Mesozoic and Cenozoic sequence chronostratigraphic framework of European basins]. Society of Economic Paleontologists and Mineralogists Special Publication, 60:chart 7.

Wille, W. \& Gocht, H. 1979. Fossil vergesellschaftung Nr 92: Dinoflagellaten aus dom Lias Sudwestdeutschlands. Neues Jahrbuch für Geologie und Paläontologie, Abhandlungen, 158(2):221-258.

Williams, G. \& Bujak, J.P. 1985. Mesozoic and Cenozoic dinoflagellates. In: H.M. Bolli; J.B. Saunders \& K. Perch-Nielsen (eds.) Plankton stratigraphy, Cambridge University Press, p. 847-964.

Wood, G.D., Gabriel, A.M. \& Lawson, J.C. 1996. Palynological techniques - processing and microscopy. In: J. Jansonius \& D.C. McGregor (eds.) Palynology: principles and applications, American Association of Stratigraphic Palynologists Foundation, p. $29-50$.

Woollam, R. \& Riding, J.B. 1983. Dinoflagellate cyst zonation of the English Jurassic. Institute of Geological Sciences Report, 83(2):1-42.

Wright, V.P. \& Wilson, R.C.L. 1984. A carbonate submarine-fan sequence from the Jurassic of Portugal. Journal of Sedimentary Petrology, 54:394-412.

Received in October, 2005; accepted in January, 2007. 